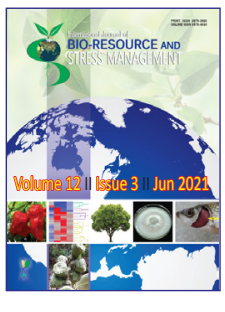

\title{
Response of Rainfed Castor to Soil and Foliar Application of Zinc and Iron Micronutrients
}

\author{
A. V. Ramanjaneyulu1 ${ }^{1 *}$, A. Madhavi², M. V. Nagesh Kumar ${ }^{3}$ and T. L. Neelima ${ }^{4}$ \\ ${ }^{1}$ Agricultural Research Station, Tornala, Telangana (502 114), India \\ ${ }^{2} \mathrm{AICRP}$ on STCR scheme, ${ }^{3}$ Dept. of Plant Breeding, Maize Research Centre, ${ }^{4}$ Water Technology Centre, Professor Jayashankar \\ Telangana State Agricultural University, Rajendranagar, Hyderabad, Telangana State (500 030), India
}

\begin{abstract}
Open Access Corresponding Author

A. V. Ramanjaneyulu

e-mail: avr_agron@rediffmail.com

Citation: Ramanjaneyulu et al., 2021. Response of Rainfed Castor to Soil and Foliar Application of Zinc and Iron Micronutrients. International Journal of Bio-resource and Stress Management 2021, 12(3), 158-164. HTTPS://DOI.ORG/10.23910/1.2021.2196.

Copyright: (c) 2021 Ramanjaneyulu et al. This is an open access article that permits unrestricted use, distribution and reproduction in any medium after the author(s) and source are credited.

Data Availability Statement: Legal restrictions are imposed on the public sharing of raw data. However, authors have full right to transfer or share the data in raw form upon request subject to either meeting the conditions of the original consents and the original research study. Further, access of data needs to meet whether the user complies with the ethical and legal obligations as data controllers to allow for secondary use of the data outside of the original study.
\end{abstract}

Funding: The research was conducted with funding under AICRP on Castor, ICAR-IIOR, Hyderabad, India.

Conflict of interests: The authors have declared that no conflict of interest exists.

\begin{abstract}
A field investigation was carried out to study the influence of zinc and iron micronutrients on the performance of rainfed castor, in Professor Jayashankar Telangana State Agricultural University, Telangana state, India for three consecutive years during kharif 2011-12, 2012-13 and 2013-14. There were nine treatments viz., Control (no micronutrient application); soil application of $\mathrm{FeSO}_{4}$ @ $15 \mathrm{~kg} \mathrm{ha}^{-1}$; soil application of FeSO $@ 25 \mathrm{~kg} \mathrm{ha}^{-1}$; soil application of $\mathrm{ZnSO}_{4} @$ $15 \mathrm{~kg} \mathrm{ha}^{-1}$; soil application of $\mathrm{ZnSO}_{4} @ 25 \mathrm{~kg} \mathrm{ha}^{-1}$; foliar application of $0.5 \% \mathrm{FeSO}_{4}$ at 50 DAS; foliar application of $0.5 \% \mathrm{FeSO}_{4}$ at 50 and $90 \mathrm{DAS}$; foliar application of $0.5 \% \mathrm{ZnSO}_{4}$ at $50 \mathrm{DAS}$; foliar application of $0.5 \% \mathrm{ZnSO}_{4}$ at 50 and $90 \mathrm{DAS}$ and tested in randomized block design with three replications. The foliar application of $\mathrm{ZnSO}_{4}(0.5 \%)$ twice at 50 and 90 DAS resulted in significantly higher seed yield (1698 kg ha-1), higher gross returns (Rs. 54344 ha-1 $^{-1}$ ), net returns (Rs. 33501 ha-1 $^{-1}$ ) and $\mathrm{B}: \mathrm{C}$ ratio $(2.60)$ over rest of the treatments. The seed yield improvement was to the tune of $54 \%$ over no micronutrient application. The uptake of major and micronutrients was greater when the crop received two sprays of $\mathrm{ZnSO}_{4}$ as compared to one spray of $\mathrm{ZnSO}_{4}$, two sprays of $\mathrm{FeSO}_{4}$ and soil application of either of the micronutrients. The castor bean crop responded to $\mathrm{Zn}$ better than Fe by producing $10.2 \%$ to $12.2 \%$ higher seed yield. Foliar spray was found superior to soil application in case of both the micronutrients.
\end{abstract}

Keywords: Castor, economics, foliar spray, iron, micronutrients, rainfed, zinc

\section{Introduction}

Castor bean (Ricinus communis L.) is an important non-edible oilseed crop having multiple uses in industrial, Agriculture and medical sectors. The moisture stress affects uptake of major and micronutrients in castor though it is drought tolerant (Tadayyon et al., 2018). It is widely grown for its oil in India, China, Brazil and Mozambique. Of late, it has been recognized as a useful plant for biofuel production (Carrino et al., 2020) and phytoremediation of arsenic contaminated soils and hyper accumulation of nickel (Malarkodi et al., 2008). In general, crops need micro nutrients besides macro and secondary nutrients for proper growth, development and achieving better yields. A decline in the availability of such nutrients due to either non-application, moisture

Article History

RECEIVED on $17^{\text {th }}$ March 2021 RECEIVED in revised form on $18^{\text {th }}$ May 2021 ACCEPTED in final form on $10^{\text {th }}$ June 2021 
stress or soil inherent problems, reduces yield drastically. In India, the castor bean is cultivated under rainfed and irrigated conditions due to the availability of high yielding, pest and disease resistant hybrids in both public and private domain. India has exported castor oil worth more than USD 59.89 million during 2020 (Anonymous, 2021), thus, the crop has high export potential. However, this oilseed plant is often grown on marginal soils having many constraints (Rego et al., 2007). Continuous cultivation of castor bean crop on less fertile Alfisols especially under rainfed conditions led to the emergence of micronutrient deficiencies resulting in inferior productivity levels of $500-600 \mathrm{~kg} \mathrm{ha}^{-1}$. A castor crop yielding 2.3 t ha ${ }^{-1}$ of seed removed $105 \mathrm{~kg} \mathrm{~N} \mathrm{ha}^{-1}$ from soil (Ramanjaneyulu et al., 2013). Further, a crop with $1.37 \mathrm{t} \mathrm{ha}^{-1}$ yield potential has removed $86.6 \mathrm{~g} \mathrm{Zn} \mathrm{ha}^{-1}$ on Alfisols (Suresh et al., 2013). Among micronutrients, $\mathrm{Zn}$ and Fe gained macro importance, hence, their adequate supply is essential for better growth and yield. Their bioavailability is very important for nutritional security of the vegetarian community (Ganeshmurthy et al., 2017). In semiarid regions of India where deficiency of $S, B$ and $\mathrm{Zn}$ are widespread, their supply improved the seed yield of rainfed castor from 757 to $1043 \mathrm{~kg} \mathrm{ha}^{-1}$ with a 38\% yield advantage, which is more than that obtained with the addition of $\mathrm{N}$ and $\mathrm{P}$ (15\%) (Sahrawat, 2010). Agricultural soils in India are deficient in Zn and deficient to sufficient in Fe. Further, Zn deficiency may aggravate in the coming years from $42 \%$ (1975) to $63 \%$ (2025) following the adoption of intensive cropping systems without supplementation with organic manures and micronutrients and excessive application of phosphatic fertilizers. Similarly, $12-15 \%$ soils are deficient in iron (Singh, 2008). Zinc (Zn) plays a pivotal role in the proper functioning of various enzymes in carbohydrate and protein metabolism, photosynthesis, growth regulation, sugar to starch conversion and resistance to certain disease causing pathogens (Alloway, 2008), affects chloroplasts, thylakoids and amyloplasts (Junior et al., 2012). Further, it is needed for proper flowering, pollen formation and fruit or seed development. Hence, its deficiency leads to stunted growth, 'rosette' formation and reduces crop productivity. Iron (Fe) is basically required for chlorophyll formation and maintenance of chloroplast structure and function. Its deficiency is common in rainfed upland crops especially on calcareous or alkaline soils of arid region. It's deficiency leads to interveinal chlorosis of young leaves and stunted growth leading to poor yield and quality. It becomes deficit under low moisture stress thus less available to the plant. While, under excess moisture, its availability is increased and becomes toxic. Thus, iron stress is considered as a serious problem as it is limiting yields of many crops across the globe (Prasad and Shivay, 2021). Balanced nutrition with the inclusion of micronutrients in crop nutrient management is gaining importance across crops and agro-climatic zones in order to improve or sustain crop productivity and ensure an adequate supply of food, feed and fiber for the growing population (Malavolta et al., 2006; Taylor and Townsend, 2010). However, such studies are very less in castor bean.
Hence, an attempt was made to quantify the impact of zinc and iron nutrition on the performance of rainfed castor crop grown on Alfisols.

\section{Materials and Methods}

\subsection{Study site and year of experimentation}

The three year field study was executed during kharif (July to January) season of 2011-12 to 2013-14 in Professor Jayashankar Telangana State Agricultural University (PJTSAU), Telangana, India to quantify the impact of micronutrient application on the performance of rainfed castor. The study site was located at $16^{\circ} 35^{\prime} \mathrm{N}$ latitude and $78^{\circ} 1^{\prime} \mathrm{E}$ longitude and an altitude of 642 above mean sea level (MSL) in Southern Telangana Zone (STZ). The experimental soil was near neutral with a $\mathrm{pH}$ of 6.3 , low in organic carbon $(0.3 \%)$ and available $\mathrm{N}$ $\left(220 \mathrm{~kg} \mathrm{ha}^{-1}\right)$, high in available $\mathrm{P}\left(75.1 \mathrm{~kg} \mathrm{P}_{2} \mathrm{O}_{5} \mathrm{ha}^{-1}\right)$ and $\mathrm{K}(425.6$ $\left.\mathrm{kg} \mathrm{K}_{2} \mathrm{O} \mathrm{ha}^{-1}\right)$, deficient in DTPA extractable $\mathrm{Zn}(0.25 \mathrm{ppm})$ and sufficient in DTPA extractable Fe (4.40 ppm).

\subsection{Details of treatments and agronomic operations}

The trial comprised of nine treatments viz., $\mathrm{T}_{1}$ : Control (no micronutrient application); $\mathrm{T}_{2}$ : Soil application of $\mathrm{FeSO}_{4} @$ $15 \mathrm{~kg} \mathrm{ha}^{-1}$ (2.93 kg Fe ha ${ }^{-1}$ ); $\mathrm{T}_{3}$ : Soil application of FeSO $@ 25$ kg ha-1 (4.88 kg Fe ha-1); $\mathrm{T}_{4}$ : Soil application of $\mathrm{ZnSO}_{4} @ 15$ $\mathrm{kg} \mathrm{ha}^{-1}$ (3.15 kg Zn ha-1); $\mathrm{T}_{5}$ : Soil application of $\mathrm{ZnSO}_{4} @ 25 \mathrm{~kg}$ $\mathrm{ha}^{-1}\left(5.25 \mathrm{~kg} \mathrm{Zn} \mathrm{ha}^{-1}\right) ; \mathrm{T}_{6}$ : Foliar application of $0.5 \% \mathrm{FeSO}_{4}$ at 50 DAS $\left(0.488 \mathrm{~kg} \mathrm{Fe} \mathrm{ha}^{-1}\right) ; \mathrm{T}_{7}$ : Foliar application of $0.5 \% \mathrm{FeSO}_{4}$ at 50 and 90 DAS $\left(0.975 \mathrm{~kg} \mathrm{Fe} \mathrm{ha}^{-1}\right) ; \mathrm{T}_{8}$ : Foliar application of $0.5 \% \mathrm{ZnSO}_{4}$ at 50DAS $\left(0.525 \mathrm{~kg} \mathrm{Zn} \mathrm{ha}^{-1}\right) ; \mathrm{T}_{9}$ : Foliar application of $0.5 \% \mathrm{ZnSO}_{4}$ at 50 and $90 \mathrm{DAS}\left(1.05 \mathrm{~kg} \mathrm{Zn} \mathrm{ha}^{-1}\right)$, each replicated thrice and was conducted in a randomized block design (RBD).

The trial was taken up with a double bloom, fusarium wilt resistant and high yielding hybrid $\mathrm{PCH}-111$ and was sown on 13-07-11, 15-07-12 and 11-07-2013 at a spacing of $90 \times 60$ $\mathrm{cm}^{2}$. Each treatment had a gross plot size of $5.4 \times 6.0 \mathrm{~m}^{2}(6$ rows*10 plants) and a net plot size of $3.6 \times 4.8 \mathrm{~m}^{2}$ (4 rows*8 plants). A gap of two meters was left among treatments and replications to avoid lateral flow of rain water and nutrients. $A$ uniform nutrient dose of 80-40-30 kg N, $\mathrm{P}_{2} \mathrm{O}_{5}$ and $\mathrm{K}_{2} \mathrm{O}$ ha-1 was followed in the form of urea $(46 \% \mathrm{~N})$, single super phosphate $\left(16 \% \mathrm{P}_{2} \mathrm{O}_{5}\right)$ and muriate of potash $\left(60 \% \mathrm{~K}_{2} \mathrm{O}\right)$, respectively by pocketing method for all nine treatments. Half the dose of nitrogen, total dose of phosphorus and potash were applied as basal, while, remaining half nitrogen dose in three equal splits at 30, 60 and 90 DAS (days after sowing). The $\mathrm{Zn}$ and Fe were applied as basal through $\mathrm{ZnSO}_{4} \cdot 7 \mathrm{H}_{2} \mathrm{O}(21 \% \mathrm{Zn})$ and $\mathrm{FeSO}_{4} \cdot 7 \mathrm{H}_{2} \mathrm{O}(19.5 \% \mathrm{Fe})$, respectively in $\mathrm{T}_{2}$ to $\mathrm{T}_{5}$ treatments, while they are sprayed on to the crop foliage at the rate of $0.5 \%$ in $\mathrm{T}_{6}$ to $\mathrm{T}_{9}$ treatments. An amount of $361.2,534.0$ and $841.0 \mathrm{~mm}$ rainfall was received over 31,37 and 31 rainy days during crop growth period in 2011, 2012 and 2013 indicating $36.1 \%$ and $5.5 \%$ deficit rainfall in the first two years, but, $57.5 \%$ excess rainfall in the last year of trial. The sucking pest jassid (Empoasca flavescens Fab.) was controlled by spraying 
Acephate (1.5 $\left.\mathrm{g} \mathrm{l}^{-1}\right)$, semi looper (Achaea janata Linn.) and tobacco caterpillar (Spodopetra litura) by spraying Novoluron $\left(1 \mathrm{ml} \mathrm{l}^{-1}\right)$ twice. The weeds were controlled through preemergence application of Pendimethalin $30 \mathrm{EC}(1.0 \mathrm{~kg}$ a.i. $\left.\mathrm{ha}^{-1}\right)$ a day after sowing, two inter cultivations at 30 and 45 DAS and one hand weeding at 60 DAS.

\subsection{Data collection and chemical analysis}

The data on ancillary traits were recorded on five tagged plants in the net plot area. Plant height and number of nodes plant ${ }^{-1}$ were recorded up to the base of primary raceme. A total of three pickings were taken at monthly intervals starting from October second fortnight up to the first fortnight of January during all the years of experimentation. The racemes with $75 \%$ matured capsules were harvested using secature, sun dried for a week and then threshed by beating with wooden mallets to get seed from capsules. The seed yield from all the pickings was summed up to report the final seed yield.

The seed samples collected at primary raceme (90 DAS), secondary raceme (120 DAS) and remaining racemes maturity stage (150 DAS) were mixed and made into powder with the help of Willey mill. A similar procedure was followed for plant samples which were oven dried using a hot air oven $\left(105^{\circ} \mathrm{C}\right)$ before grinding. The samples were used for estimating $\mathrm{N}, \mathrm{P}$ and $\mathrm{K}$ content following the procedures suggested by Piper (1966) and Fe and Zn concentration using atomic absorption spectrophotometer (Sims and Johnson, 1991). The pre sowing and post harvest soil samples were collected for analyzing $\mathrm{pH}$, EC and available K (Jackson, 1973), available N (Subbaiah and Asija, 1956) and P (Olsen et al., 1954).

Use efficiency of nitrogen, zinc and iron were computed by dividing the castor seed yield by N, Zn or Fe dose applied as per the treatment and expressed in $\mathrm{kg} \mathrm{kg}^{-1}$.

The cost of cultivation (COC), gross returns (GRs), net returns (NRs) and B:C ratio were computed by the formulas furnished below.

$\begin{array}{lll}\operatorname{COC}\left(₹ h^{-1}\right) & : & \text { Input cost+labour cost } \\ \text { GRs }\left(₹ h^{-1}\right) & : & \text { Seed yield * Market price } \\ \text { NRs }\left(₹ h^{-1}\right) & : & \text { GRs-COC } \\ \text { B:C ratio } & : & \text { GRs/COC }\end{array}$

The data were subjected to RBD analysis. Further, the standard error of means (SEm \pm ) and least significant difference at $5 \%$ probability $(p=0.05$ ) were used to compare the treatments and draw valid conclusions as per the procedure by given Panse and Sukhatme (1985).

\section{Results and Discussion}

\subsection{Changes in growth and yield traits due to micronutrient application}

The plant population and number of nodes plant ${ }^{-1}$ did not differ significantly in all the nine treatments under test. Though the plant height and number of nodes plant ${ }^{-1}$ improved with micronutrient application, it did not differ significantly from that of control (no micronutrients) (Table 1). Previously, Leles et al. (2010) reported that, addition of $\mathrm{Zn}$ failed to show a significant effect on plant growth or production in a semi arid climate.

The pooled data of three years revealed that $T_{9}$ recorded significantly more number of branches plant ${ }^{-1}$ than rest of the treatments barring $\mathrm{T}_{8^{\prime}} \mathrm{T}_{7}$ (two times foliar spray of $\mathrm{FeSO}_{4} @$ $0.5 \%$ ), $\mathrm{T}_{5}$ (soil application of $\mathrm{ZnSO}_{4} @ 25 \mathrm{~kg} \mathrm{ha}^{-1}$ ) and $\mathrm{T}_{3}$ (soil application of $\left.\mathrm{FeSO}_{4} @ 25 \mathrm{~kg} \mathrm{ha}^{-1}\right)$. Quantitative enhancement

Table 1: Effect of micronutrient application on growth parameters of castor bean crop (Pooled data of Kharif, 2011-11, 2012-13 and 2013-14)

\begin{tabular}{|c|c|c|c|c|c|c|c|c|c|}
\hline Treatments & $\begin{array}{c}\text { Plant } \\
\text { population } \\
\left(\mathrm{ha}^{-1}\right)\end{array}$ & $\begin{array}{l}\text { Plant height } \\
\text { upto primary } \\
\text { raceme }(\mathrm{cm})\end{array}$ & $\begin{array}{l}\text { No. of } \\
\text { branches } \\
\text { plant }^{-1}\end{array}$ & $\begin{array}{l}\text { No. of } \\
\text { nodes } \\
\text { plant }^{-1}\end{array}$ & $\begin{array}{c}\text { Total no.of } \\
\text { racemes } \\
\text { plant }^{-1}\end{array}$ & $\begin{array}{l}\text { No.of } \\
\text { effective } \\
\text { racemes } \\
\text { plant }^{-1}\end{array}$ & $\begin{array}{c}\text { Total } \\
\text { raceme } \\
\text { length } \\
(\mathrm{cm})\end{array}$ & $\begin{array}{c}\text { Effective } \\
\text { raceme } \\
\text { length } \\
(\mathrm{cm})\end{array}$ & $\begin{array}{c}100 \\
\text { seed } \\
\text { weight } \\
\text { (g) }\end{array}$ \\
\hline $\mathrm{T}_{1}$ & 16461 & 44.6 & 3.3 & 10.7 & 4.5 & 3.0 & 41.4 & 33.1 & 27.1 \\
\hline$T_{2}$ & 16770 & 45.2 & 3.5 & 10.1 & 4.7 & 3.4 & 44.4 & 36.2 & 27.4 \\
\hline $\mathrm{T}_{3}$ & 16872 & 47.8 & 3.9 & 10.3 & 5.2 & 3.6 & 46.4 & 39.9 & 27.5 \\
\hline $\mathrm{T}_{4}$ & 16461 & 46.3 & 3.6 & 10.6 & 5.4 & 3.8 & 44.4 & 39.7 & 26.3 \\
\hline$T_{5}$ & 16838 & 49.2 & 3.8 & 10.5 & 5.3 & 3.5 & 44.9 & 40.4 & 27.5 \\
\hline $\mathrm{T}_{6}$ & 16495 & 43.6 & 3.5 & 10.4 & 5.1 & 4.3 & 42.5 & 37.4 & 26.9 \\
\hline $\mathrm{T}_{7}$ & 16804 & 49.1 & 3.9 & 10.9 & 5.4 & 4.1 & 44.7 & 42.2 & 27.3 \\
\hline $\mathrm{T}_{8}$ & 16771 & 46.9 & 3.8 & 10.2 & 5.5 & 5.1 & 44.0 & 40.3 & 27.0 \\
\hline $\mathrm{T}_{9}$ & 16632 & 50.2 & 4.5 & 10.9 & 6.5 & 5.4 & 47.4 & 45.3 & 27.6 \\
\hline SEm \pm & 274 & 1.9 & 0.2 & 0.3 & 0.3 & 0.3 & 1.7 & 1.5 & 0.4 \\
\hline $\operatorname{CD}(p=0.05)$ & NS & NS & 0.7 & NS & 1.0 & 0.8 & NS & 4.3 & NS \\
\hline
\end{tabular}


in the vegetative growth of the plant is positively correlated to the optimum application of micronutrients in castor as suggested by Rastogi et al. (2014).

The relation between increase in number of total and effective racemes plant ${ }^{-1}$ and micronutrient application has been linear (Table 1). Significantly more number was recorded with the application of $0.5 \% \mathrm{ZnSO}_{4}$ at $50 \mathrm{DAS}$ and $90 \mathrm{DAS}\left(\mathrm{T}_{9}\right)$ or 50 DAS alone $\left(\mathrm{T}_{8}\right)$.

Significantly longer effective racemes were recorded with foliar application of $0.5 \% \mathrm{ZnSO}_{4}$ at 50 and $90 \mathrm{DAS}\left(\mathrm{T}_{9}\right)$. Further, micronutrient application except soil application of FeSO $\mathrm{F}_{4}$ $15 \mathrm{~kg} \mathrm{ha}^{-1}$ greatly improved the effective raceme length over control (Table 1). The foliar spray method was found effective than soil application. Within soil, $25 \mathrm{~kg} \mathrm{ha}^{-1}$ fared better than $15 \mathrm{~kg} \mathrm{ha}^{-1}$. In the case of foliar spray, application at two crop stages was found better than one stage. This implies that micronutrients play a major role in enzymatic activities which in turn improved productive traits. The results of data pooled over three years revealed that the addition of micronutrients did not bring out any significant change in 100 seed weight (Table 1).

\subsection{Changes in seed yield of castor due to micronutrient application}

The trend in seed yield of castor bean crop was similar regardless of year of trial (Table 2). The differential yield in three years was due to variations in rainfall. The yield levels were comparatively higher during the second year (2012-13) due to receipt of normal rainfall, while it was low during the first year (2011-12) due to $36.1 \%$ deficit rainfall and $57.5 \%$ excess rainfall during the third year. The low rainfall conditions have created a dry spell which affected the growth and yield during the first year. On the other hand, higher rainfall during the third year led to the incidence of Botryotinia gray mold on castor racemes. The data pooled over three years indicated that control treatment which excludes micronutrient application resulted in significantly lower seed yield $(1100 \mathrm{~kg}$ $\left.\mathrm{ha}^{-1}\right)$. The seed yield improved linearly with the application of Fe or Zn either through soil application or foliar spray. Application of $\mathrm{FeSO}_{4}$ or $\mathrm{ZnSO}_{4}$ resulted in significantly higher seed yield over soil application of respective micronutrients. One time foliar spray of $\mathrm{FeSO}_{4}$ was found at par with its soil application @ $25 \mathrm{~kg} \mathrm{ha}^{-1}$, but, significantly superior to $15 \mathrm{~kg}$ $\mathrm{ha}^{-1}$. Further, two times foliar spray of $\mathrm{FeSO}_{4}$ being at par with one time foliar spray of $\mathrm{FeSO}_{4}$ and soil application of $25 \mathrm{~kg}$ $\mathrm{FeSO}_{4} \mathrm{ha}^{-1}$, but, significantly superior to soil application of 15 $\mathrm{kg} \mathrm{FeSO}_{4} \mathrm{ha}^{-1}$. Though, the seed yield obtained due to two foliar sprays of $\mathrm{ZnSO}_{4}$ at par with one spray, but, significantly greater to its soil application either at 15 and $25 \mathrm{~kg} \mathrm{ha}^{-1}$. Application of 15 and $25 \mathrm{~kg} \mathrm{ha}^{-1}$ resulted in similar seed yields in both the micronutrients. Similarly, one and two foliar sprays did not differ significantly with regard to seed yield of castor bean. Of all the nine treatments evaluated, foliar application of $\mathrm{ZnSO}_{4} @ 0.5 \%$ twice at 50 and 90 DAS ( $\left.\mathrm{T}_{9}: 1698 \mathrm{~kg} \mathrm{ha}^{-1}\right)$ being at par with foliar application of $\mathrm{ZnSO}_{4} @ 0.5 \%$ once at 50 DAS (1589 $\mathrm{kg} \mathrm{ha}^{-1}$ ) was found to be significantly superior to the rest of the treatments (Table 2). The seed yield improvement was to the tune of $7 \%\left(109 \mathrm{~kg} \mathrm{ha}^{-1}\right)$ to $54 \%\left(598 \mathrm{~kg} \mathrm{ha}^{-1}\right)$, the highest being over no micronutrient application. Significantly more number of branches plant ${ }^{-1}$, total and effective number

Table 2: Effect of micronutrient application on seed yield, nutrient use efficiency and economics of castor bean crop (Kharif 2011-11, 2012-13 and 2013-14)

\begin{tabular}{|c|c|c|c|c|c|c|c|c|c|c|c|c|c|c|}
\hline \multirow{2}{*}{$\begin{array}{l}\text { Treat- } \\
\text { ments }\end{array}$} & \multicolumn{4}{|c|}{ Seed yield $\left(\mathrm{kg} \mathrm{ha}^{-1}\right)$} & \multirow[t]{2}{*}{ YID } & \multirow{2}{*}{$\begin{array}{c}\% \\
\text { YID }\end{array}$} & \multirow{2}{*}{$\begin{array}{c}\text { FeUE } \\
\left(\mathrm{kg} \mathrm{kg}^{-1}\right)\end{array}$} & \multirow{2}{*}{$\begin{array}{c}\text { ZnUE } \\
\left(\mathrm{kg} \mathrm{kg}^{-1}\right)\end{array}$} & \multirow{2}{*}{$\begin{array}{c}\text { NUE } \\
\left(\mathrm{kg} \mathrm{kg}^{-1}\right)\end{array}$} & \multirow[t]{2}{*}{ GR } & \multirow[t]{2}{*}{ NR } & \multirow[t]{2}{*}{ ARD } & \multirow{2}{*}{$\begin{array}{l}\% \\
\text { ID }\end{array}$} & \multirow{2}{*}{$\begin{array}{l}\mathrm{B}: \mathrm{C} \\
\text { ratio }\end{array}$} \\
\hline & $\begin{array}{c}2011- \\
12\end{array}$ & $\begin{array}{c}2012- \\
13\end{array}$ & $\begin{array}{c}2013- \\
14\end{array}$ & Pooled & & & & & & & & & & \\
\hline $\mathrm{T}_{1}$ & 869 & 1404 & 1026 & 1100 & & & & & 13.8 & 35286 & 15036 & 18465 & 123 & 1.73 \\
\hline $\mathrm{T}_{2}$ & 995 & 1736 & 1078 & 1270 & 598 & 54 & - & - & 15.9 & 40554 & 19190 & 14311 & 75 & 1.89 \\
\hline $\mathrm{T}_{3}$ & 1075 & 1824 & 1162 & 1354 & 428 & 34 & 433 & - & 16.9 & 43261 & 21423 & 12078 & 56 & 1.97 \\
\hline $\mathrm{T}_{4}$ & 1234 & 1800 & 1212 & 1415 & 344 & 25 & 277 & - & 17.7 & 45294 & 23869 & 9632 & 40 & 2.11 \\
\hline $\mathrm{T}_{5}$ & 1394 & 1878 & 1313 & 1528 & 283 & 20 & - & 449 & 19.1 & 48965 & 27023 & 6478 & 24 & 2.24 \\
\hline $\mathrm{T}_{6}$ & 1225 & 1966 & 1208 & 1466 & 170 & 11 & - & 291 & 18.3 & 46815 & 26289 & 7212 & 27 & 2.28 \\
\hline $\mathrm{T}_{7}$ & 1331 & 1916 & 1305 & 1517 & 232 & 16 & 3004 & - & 19.0 & 48583 & 27780 & 5721 & 21 & 2.33 \\
\hline $\mathrm{T}_{8}$ & 1344 & 2105 & 1317 & 1589 & 181 & 12 & 1556 & - & 19.9 & 50755 & 30214 & 3287 & 11 & 2.47 \\
\hline $\mathrm{T}_{9}$ & 1419 & 2213 & 1463 & 1698 & 109 & 7 & - & 3027 & 21.2 & 54334 & 33501 & - & - & 2.60 \\
\hline SEm \pm & 99 & 107 & 60 & 59 & - & - & - & 1617 & 0.8 & & & - & & \\
\hline $\begin{array}{l}C D \\
(p=0.05)\end{array}$ & 298 & 317 & 183 & 167 & & & & & 2.4 & & & & & \\
\hline
\end{tabular}

YID: Yield increase due to $\mathrm{T}_{9}\left(\mathrm{~kg} \mathrm{ha}^{-1}\right) ; \%$ YID: \% yield increase due to $\mathrm{T}_{9}$; GR: Gross returns (₹ ha-1 $)$; NR: Net returns $\left(₹ \mathrm{ha}{ }^{-1}\right)$; ARD: Additional net returns due to $\mathrm{T}_{9}$ Over other treatments (₹ ha-1); \% ID: \% increase due to $\mathrm{T}_{9}$ over others 
of racemes plant ${ }^{-1}$ and effective raceme length might have contributed to higher seed yield in $\mathrm{T}_{9}$. Furthermore, foliar spray might have supplied the nutrients readily to the plant and thereby transformation from store parts to sink parts regardless of soil moisture, which, otherwise it is difficult for the plant to absorb the same from soil in the absence of optimum soil moisture. Earlier, Rastogi et al. (2014) reported a positive correlation between $\mathrm{Zn}$ supply and seed yield. Further, the synergistic effect of inorganic nutrients and Zinc sulphate could have positively improved growth and yield attributes. Though such studies are meager in castor, but, it is understood that two times foliar spray of micronutrients at flowering and podding stage in soybean had significant effect on stamens and pollens which inturn increased number of pods per plant and seed yield (Nadergholi et al., 2011). The response of castor bean to foliar spray was better than soil application irrespective of $\mathrm{Zn}$ or Fe. According to Murthy and Muralidharudu (2003) and Mathukia and Khanpara (2008), application of Zinc @ $5 \mathrm{~kg} \mathrm{ha}^{-1}$ was found optimum for achieving higher dry matter production, $11.5 \%$ higher seed yield and zinc use efficiency in rainfed castor. Further, the response was higher when micronutrients were applied in integration with macronutrients. Application of $50 \mathrm{~kg} \mathrm{ha}^{-1}$ $\mathrm{ZnSO}_{4}$ resulted in better growth and yield attributes and $11.0 \%$ and $18.4 \%$ yield improvement over no $\mathrm{Zn}$ application on medium black calcareous soils in Western India (Polara et al., 2010).

In the current experiment, the yield improvement was high $(54 \%)$ due to low zinc content at the experimental site. Crops and varieties vary in their response to micronutrient application depending on the soil type and condition, moisture availability, method of application, type of crop, concentration of the nutrient in the soil and spray fluid. Sakal (2001) and Gupta et al. (2007) reported the superiority of foliar spray to soil application. In the present experiment also, castor bean which was grown rainfed, responded better to foliar spray as compared to that of soil application. The primary reason for this could be low or excessive soil moisture stress. Such results were published earlier by Salamatbakhsh et al. (2012) who observed no significant difference in number of leaves, seeds and racemes plant ${ }^{-1}$, but, reported significantly more number of fertile capsules plant ${ }^{-1}$ and 100 seed weight and $50 \%$ improvement in castor seed yield, when foliar feeding of micronutrients was done twice i.e. flowering stage of primary raceme and secondary racemes control. The results of several field experiments have shown that micronutrients improved crop yield and quality significantly. In fact, photosynthesis and the regulation of transpiration are the primary tasks of foliage. The advantage of nutrient uptake through foliage is that nutrient absorption is quick and directly to the leaf cells and will be utilized for further growth and development and improve dry matter transformation from source to sink. Our research further highlighted the importance of balanced fertilization involving micro and macronutrients for the significant increase in yield. The castor bean crop performed better when sprayed twice than once, which might be to meet the growing nutritional demand from primary, secondary and tertiary racemes. Further, the use efficiency of $\mathrm{Zn}$ or Fe was higher when they are applied through foliar spray than soil. Application of micronutrients improved the nitrogen use efficiency (NUE) significantly (15.9 to $21.2 \mathrm{~kg} \mathrm{~kg}^{-1}$ ) over control (13.8 $\mathrm{kg} \mathrm{kg}^{-1}$ ) (Table 3).

\subsection{Economics}

Foliar spray of $\mathrm{ZnSO}_{4}$ twice at 50 and 90 DAS resulted in higher gross returns ( $₹ 54344 \mathrm{ha}^{-1}$ ), net returns ( $₹ 33501 \mathrm{ha}^{-1}$ ) and B:C ratio (2.60) (Table 2). It gave $11-123 \%$ higher additional net returns ( $₹ 3287$ to 18465 ha $^{-1}$ ) over other treatments and the highest being over no micronutrient application.

Table 3: Effect of micronutrient application on N, P, K, Fe and Zn concentration in castor bean crop (Pooled data of 2011-12 to 2013-14)

\begin{tabular}{|c|c|c|c|c|c|c|c|c|c|c|c|c|c|c|c|}
\hline \multirow{2}{*}{$\begin{array}{l}\text { Treat- } \\
\text { ments }\end{array}$} & \multicolumn{3}{|c|}{ N (\%) } & \multicolumn{3}{|c|}{$\mathrm{P}_{2} \mathrm{O}_{5}(\%)$} & \multicolumn{3}{|c|}{$\mathrm{K}_{2} \mathrm{O}(\%)$} & \multicolumn{3}{|c|}{$\mathrm{Fe}(\mathrm{ppm})$} & \multicolumn{3}{|c|}{$\mathrm{Zn}(\mathrm{ppm})$} \\
\hline & Stalk & Seed & Total & Stalk & Seed & Total & Stalk & Seed & Total & Stalk & Seed & Total & Stalk & Seed & Total \\
\hline $\mathrm{T}_{1}$ & 1.69 & 1.85 & 3.54 & 0.37 & 0.35 & 0.72 & 0.94 & 1.70 & 2.64 & 70.5 & 84.7 & 155.2 & 22.5 & 22.2 & 44.8 \\
\hline$T_{2}$ & 1.59 & 1.70 & 3.30 & 0.33 & 0.35 & 0.68 & 0.93 & 1.59 & 2.51 & 61.3 & 94.7 & 156.0 & 21.0 & 22.0 & 43.0 \\
\hline $\mathrm{T}_{3}$ & 1.52 & 1.72 & 3.24 & 0.34 & 0.35 & 0.69 & 0.95 & 1.52 & 2.47 & 62.1 & 95.3 & 157.5 & 20.8 & 22.4 & 43.2 \\
\hline $\mathrm{T}_{4}$ & 1.50 & 1.82 & 3.31 & 0.34 & 0.36 & 0.70 & 0.97 & 1.55 & 2.52 & 64.7 & 87.6 & 152.3 & 19.3 & 23.7 & 43.1 \\
\hline $\mathrm{T}_{5}$ & 1.56 & 1.80 & 3.35 & 0.36 & 0.33 & 0.70 & 0.94 & 1.49 & 2.43 & 64.5 & 87.2 & 151.7 & 22.9 & 25.0 & 47.8 \\
\hline$T_{6}$ & 1.49 & 1.93 & 3.42 & 0.33 & 0.38 & 0.71 & 0.92 & 1.55 & 2.47 & 68.9 & 95.9 & 164.8 & 24.4 & 23.4 & 47.8 \\
\hline $\mathrm{T}_{7}$ & 1.45 & 1.79 & 3.24 & 0.36 & 0.34 & 0.70 & 0.94 & 1.66 & 2.60 & 68.8 & 85.5 & 154.3 & 25.0 & 23.1 & 48.1 \\
\hline $\mathrm{T}_{8}$ & 1.52 & 1.68 & 3.20 & 0.33 & 0.36 & 0.69 & 0.84 & 1.62 & 2.47 & 67.5 & 89.1 & 156.5 & 24.7 & 24.8 & 49.5 \\
\hline $\mathrm{T}_{9}$ & 1.56 & 1.87 & 3.43 & 0.34 & 0.38 & 0.72 & 0.97 & 1.66 & 2.63 & 63.7 & 88.5 & 152.3 & 26.2 & 23.7 & 49.8 \\
\hline SEm \pm & 0.10 & 0.14 & 0.18 & 0.03 & 0.03 & 0.03 & 0.03 & 0.08 & 0.09 & 0.62 & 1.3 & 1.3 & 0.5 & 0.4 & 0.7 \\
\hline $\mathrm{CD}(p=0.05)$ & NS & NS & NS & NS & NS & NS & NS & NS & NS & 1.9 & 3.9 & 3.8 & 1.6 & 1.2 & 2.1 \\
\hline
\end{tabular}


Foliar spray of either Zn or Fe was found better than soil application due to higher net returns following higher yield. Further, foliar spray was economical due to less dose $(2.5 \mathrm{~kg}$ $\mathrm{ha}^{-1}$ ) than soil application (15 or $25 \mathrm{~kg} \mathrm{ha}^{-1}$ ). Moreover, the micronutrients can be also applied by tank mixing with plant protection chemicals thus avoids double cost. Nevertheless, the absorption and use efficiency of micronutrients were higher when sprayed on to foliage than soil application as the latter one needs optimum soil moisture for solubility, nutrient uptake by roots and transportation to shoots and reproductive parts (Garg, 2003). Lack of optimum moisture in the soil during the first year might have impaired nutrient uptake and excess soil moisture during the third year of the trial might have drained away the nutrients making them unavailable to the plant. Hence, foliar spray has given better results than soil application.

\subsection{Nutrient concentration and uptake}

Micronutrient application did not change significantly the concentration of N, P and $\mathrm{K}$ in castor stalk and seed (Table 3). It is similar in the case of total concentration too. In case of micronutrients, significantly higher Fe concentration in stalk was observed in the control plot $\left(T_{1}\right)$, while, higher seed and total Fe was recorded in T6 (one time foliar spray of FeSO at 50 DAS). Further, $\mathrm{Zn}$ in castor stalk was highest when the crop received foliar spray of $\mathrm{ZnSO}_{4}$ twice at 50 and 90 DAS $\left(\mathrm{T}_{9}\right)$, but, it was par with that of two sprays of $\mathrm{FeSO}_{4}\left(\mathrm{~T}_{8}\right)$ and one spray of $\mathrm{ZnSO}_{4}\left(\mathrm{~T}_{7}\right)$. While, $\mathrm{Zn}$ in castor seed was higher due to soil application of $\mathrm{ZnSO}_{4} @ 25 \mathrm{~kg} \mathrm{ha}^{-1}$ as basal $\left(\mathrm{T}_{5}\right)$ and one time foliar spray of $\mathrm{FeSO}_{4}$ at $50 \mathrm{DAS}\left(\mathrm{T}_{8}\right)$. The total $\mathrm{Zn}$ content was significantly greater due to two sprays of $\mathrm{ZnSO}_{4}$ than the rest of the treatments barring one time $\mathrm{ZnSO}_{4}$ spray, one or two sprays of $\mathrm{FeSO}_{4}$ and soil application of $\mathrm{ZnSO}_{4} @ 25 \mathrm{~kg} \mathrm{ha}^{-1}$. The castor bean crop accumulated significantly less amount of nutrients viz., N, P, K, Fe and Zn, when it was not supplied with micronutrients (Table 4). However, the relation between micronutrient application (either soil or foliar) and nutrient uptake was found to be linear.

Significantly greater amount of N, P, K, Fe and Zn were accumulated by the castor bean plant when the crop received foliar spray of $\mathrm{ZnSO}_{4}$ at two stages $\left(\mathrm{T}_{9}\right)$. This was mainly due to the realization of significantly higher seed and stalk yield. However, $T_{9}$ was at par with that of $T_{8}, T_{7}, T_{6}$ and $T_{5}$ for total $\mathrm{N}$ and $\mathrm{P}$, stalk and total Fe uptake; $\mathrm{T}_{8}$ and $\mathrm{T}_{7}$ for seed and total $\mathrm{K} ; \mathrm{T}_{8}$ and $\mathrm{T}_{6}$ for $\mathrm{P}$ and Fe uptake by seed and only $\mathrm{T}_{8}$ for stalk, seed and total Zn uptake. Further, higher seed and stalk yield and greater nutrient removal in $\mathrm{T}_{9}$ treatment might be due to synergistic effect between the applied macronutrients and zinc (Kumar and Kanjana, 2009). The earlier researchers Junior et al. (2012) reported higher concentration and removal of $\mathrm{Zn}$ in castor bean plants with increased micronutrient availability, under green house conditions.

\begin{tabular}{|c|c|c|c|c|c|c|c|c|c|c|c|c|c|c|c|}
\hline \multirow{2}{*}{$\begin{array}{l}\text { Treat- } \\
\text { ments }\end{array}$} & \multicolumn{3}{|c|}{$\mathrm{N}$ uptake $\left(\mathrm{kg} \mathrm{ha}^{-1}\right)$} & \multicolumn{3}{|c|}{ P uptake $\left(\mathrm{kg} \mathrm{ha}^{-1}\right)$} & \multicolumn{3}{|c|}{ K uptake (kg ha-1) } & \multicolumn{3}{|c|}{ Fe uptake (g ha-1) } & \multicolumn{3}{|c|}{ Zn uptake (g ha-1) } \\
\hline & Stalk & Seed & Total & Stalk & Seed & Total & Stalk & Seed & Total & Stalk & Seed & Total & Stalk & Seed & Total \\
\hline $\mathrm{T}_{1}$ & 27.9 & 20.4 & 48.3 & 6.1 & 3.8 & 10.0 & 15.5 & 18.7 & 34.2 & 116.2 & 93.1 & 209.3 & 37.1 & 24.4 & 61.6 \\
\hline $\mathrm{T}_{2}$ & 30.4 & 21.5 & 51.9 & 6.3 & 4.4 & 10.7 & 17.6 & 20.2 & 37.8 & 116.6 & 120.0 & 236.6 & 39.9 & 27.9 & 67.8 \\
\hline $\mathrm{T}_{3}$ & 30.9 & 23.3 & 54.2 & 6.9 & 4.7 & 11.5 & 19.4 & 20.4 & 39.8 & 126.0 & 128.9 & 254.9 & 42.2 & 30.3 & 72.6 \\
\hline $\mathrm{T}_{4}$ & 31.8 & 25.6 & 57.4 & 7.3 & 5.1 & 12.3 & 20.7 & 21.9 & 42.5 & 137.1 & 123.8 & 260.9 & 41.0 & 33.6 & 74.6 \\
\hline $\mathrm{T}_{5}$ & 35.4 & 27.3 & 62.7 & 8.4 & 5.0 & 13.4 & 21.6 & 22.8 & 44.4 & 147.6 & 133.0 & 280.7 & 52.4 & 38.1 & 90.4 \\
\hline $\mathrm{T}_{6}$ & 32.9 & 28.2 & 61.1 & 7.3 & 5.6 & 12.9 & 20.3 & 22.8 & 43.0 & 151.4 & 140.3 & 291.7 & 53.6 & 34.3 & 87.9 \\
\hline $\mathrm{T}_{7}$ & 33.0 & 27.1 & 60.1 & 8.2 & 5.2 & 13.4 & 21.4 & 25.1 & 46.5 & 156.5 & 129.6 & 286.1 & 57.0 & 35.0 & 92.0 \\
\hline $\mathrm{T}_{8}$ & 36.2 & 27.0 & 63.1 & 8.0 & 5.7 & 13.6 & 20.2 & 25.8 & 46.0 & 161.0 & 141.5 & 302.5 & 59.0 & 39.4 & 98.4 \\
\hline $\mathrm{T}_{9}$ & 39.8 & 32.0 & 71.8 & 8.7 & 6.4 & 15.1 & 24.8 & 28.2 & 53.0 & 162.1 & 150.2 & 312.3 & 66.6 & 40.1 & 106.6 \\
\hline SEm \pm & 2.4 & 2.4 & 4.1 & 0.8 & 0.4 & 0.7 & 1.3 & 1.4 & 2.5 & 6.8 & 6.0 & 12.6 & 2.8 & 1.6 & 4.2 \\
\hline $\mathrm{CD}(p=0.05)$ & NS & NS & 12.5 & NS & 1.1 & 2.3 & 4.0 & 4.3 & 7.4 & 20.1 & 18.1 & 35.2 & 8.4 & 4.7 & 12.8 \\
\hline
\end{tabular}

\section{Conclusion}

Foliar spray of $\mathrm{ZnSO}_{4}(0.5 \%)$ twice at 50 and 90 DAS could be recommended for rainfed castor due to realisation of higher productivity (1698 $\mathrm{kg} \mathrm{ha}^{-1}$ ) and net returns ( $\left.₹ 33501 \mathrm{ha}^{-1}\right)$ and returns per rupee invested (2.60). Further, foliar spray was proved better than soil application in improving castor seed yield by $12.6 \%$ and use efficiency of applied nutrients by six times. The castor bean yield improved by $10.2-12.2 \%$ when nourished with $\mathrm{ZnSO}_{4}$ than $\mathrm{FeSO}_{4}$. Thus, this study emphasized the role of balanced nutrition involving major and minor nutrients in accruing macro benefits in rainfed castor.

\section{References}

Alloway, B.J., 2008. Zinc in soils and crop nutrition ( $2^{\text {nd }}$ Edn.). Brussels, Belgium: IZA; and Paris, France: IFA. 135.

Anonymous, 2021. Statistical update on vegetable oils. https://seaofindia.com/category/statistical-update/ Accessed on 16-03-2021.

Carrino, L., Visconti, D., Fiorentino, N., Fagnano, M., 2020. Biofuel production with castor bean: A win-win strategy 
for marginal land. Agronomy 10(11), 1690. doi:10.3390/ agronomy 10111690.

Ganeshmurthy, A.N., Kalaivanan, D., Manjunath, B.L., 2017. Nutrients removed from the soil decide the nutritional security of a nation: the case of iron and zinc in India. Current Science 113(6), 1167-1173.

Garg, B.K., 2003. Nutrient uptake and management under drought: nutrient-moisture interaction. Current Agriculture 27(1-2), 1-8.

Gupta, S.P., Singh, M.V., Dixit, M.L., 2007. Deficiency and management of micronutrients. Indian Journal of Fertilizers 3(5), 57-60. https://seaofindia.com/ category/statistical-update/export-of-castor-oil/

Jackson, H.L., 1973. Soil Chemical Analysis.Prentice Hall of Inco. New York, USA. 498.

Junior, J.L., Cabral, C.P., Rossi, M.L., Nogueira, T.A.R., Nogueira, N.L., Malavolta, E., 2012. Deficiency symptoms and uptake of micronutrients by castor bean grown in nutrient solution. Revista Brasileira De Ciencia Do Solo 36, 233-242.

Kumar, N.S., Kanjana, D., 2009. Influence of integrated nutrient management practices on yield attributes, seed yield, oil yield and nutrient uptake of castor under irrigated conditions. Indian Journal of Agricultural Research 43(3), 200-205.

Leles, E.P., Fernandes, D.M., Silva, J.I.C., Fumes, L.A.A., 2010. Interaction of lime and zinc levels in the morphologic characteristics and production components of castor bean plants. Acta Scientiarum Agronomy 32, 501-509.

Malarkodi, M., Krishnasamy, R., Chitdeshwari, T., 2008. Phytoextraction of Nickel contaminated soil using castor phytoextractor. Journal of Plant Nutrition 31(2), 219-229.

Malavolta, E., Vitti, G.C., Oliveira, S.A., 2006. Availability of estimated nutrition to plants; Principles of application. Revista Brasileira de Fruticultura 28(3), 506-511.

Mathukia, R.K., Khanpara, V.D., 2008. Effect of insitu moisture conservation and zinc fertilization on soil properties and productivity of castor (Ricinus communis L.). Indian Journal of Dryland Agricultural Research and Development 23(1), 110-111.

Murthy, I.Y.L.N., Muralidharudu, Y.J., 2003. Evaluation of castor genotypes under low zinc Alfisols. Journal of Oilseeds Research 20(1), 156-157.

Nadergholi, M.S., Yarnia, M., Khoei, F.R., 2011. Effect of zinc and manganese and their application method on yield and yield components of common bean (Phaseolus vulgaris L. CV. Khomein). Middle-East Journal of Science and Research 8(5), 859-865.

Olsen, S.R., Cole, C.W., Watanabe, R.S., Dean, L.A., 1954. Estimation of available phosphorus in soils by extraction with sodium carbonate. US Department of Agriculture 2, 939.

Panse, V.G., Sukhatme, P.V., 1985. Statistical Methods for Agricultural Workers. ICAR, New Delhi.

Piper, C.S., 1966. Soil and plant analysis. Inter science publishers, New York. 59.
Polara, K.B., Sakarvadia, H.L., Babariya, N.B., Parmar, K.B., 2010. Effect of potassium and zinc on yields and nutritients uptake by castor. An Asian Journal of Soil Science 4(2), 304-307.

Prasad, R., Shivay, Y.S., 2021. Iron stress in crop plants and ways to overcome it. International Journal of Bioresource and Stress Management 12(1), i-iii. DOI: https://DOI.ORG/10.23910/1.2021.2144b.

Ramanjaneyulu, A.V., Vishnuvardhan Reddy, A., Madhavi, A., 2013. The impact of sowing date and irrigation regime on castor (Ricinus communis L.) seed yield, oil quality characteristics and fatty acid composition during post rainy season in South India. Industrial Crops and Products 44, 25-31.

Rastogi, A., Kishore, B., Mishra, M., Singh Ritu, M., Sudhir, S., 2014. Role of micronutrients on quantitative traits and prospects of its accumulation in linseed (Linum usitatissimum L.). Archives of Agronomy and Soil Science 60(10), 1389-1409.

Rego, T.J., Sahrawat, K.L., Wani, S.P., Pardhasaradhi, G., 2007. Widespread deficiencies of Sulfur, Boron, and Zinc in Indian Semi-Arid Tropical Soils: On-Farm Crop Responses. Journal of Plant Nutrition 30, 1569-1583.

Sahrawat, K.L., 2010. Soil fertility in flooded and non-flooded irrigated rice systems. Archives of Agronomy and Soil Science 58, 423-436.

Sakal, R., 2001. Efficient management of micronutrients for sustainable crop production. Journal of Indian Society of Soil Science 49(4), 593-608.

Salamatbakhsh, M.R., Tobe, A., Taherifard, E., 2012. Effects of foliar application of micronutrients on yield and yield components of castor bean (Ricinus communis L.) varieties. European Journal of Experimental Biology 2(4), 975-979.

Sims, J.T., Johnson, G.V., 1991. Micronutrients in Agriculture. Soil Science Society of America, Madison, U.S.A. 50 p.

Singh, M.V., 2008. Micronutrient deficiencies in crops and soils in India. In: Alloway, B.J. (Eds.), Micronutrient deficiencies in global crop production. Springer, Dordrecht. https://doi.org/10.1007/978-1-40206860-6874.

Suresh, G., Murthy, I.Y.L.N., Sudhakara Babu, S.N., Varaprasad, K.S., 2013. An overview of zinc use and its management in oilseed crops. Journal of SAT Agricultural Research 11, 1-11.

Subbaiah, B.V., Asija, G.L., 1956. A rapid procedure for estimation of available nitrogen in soils. Current Science 65(7), 477-480.

Tadayyon, A., Nikneshan, P., Pessarakli, M., 2018. Effects of drought stress on concentration of macro and micronutrients in castor (Ricinus communis L.) plant. Journal of Plant Nutrition 41(3), 304-310.

Taylor, P.G., Townsend, A.R., 2010. Stoichiometric control of organic carbon-nitrate relationships from soils to the sea. Nature 464, 1178-1181. 